Research paper

\title{
Widespread occurrence of methane seeps in deep-water regions of Krishna-Godavari basin, Bay of Bengal
}

\author{
P. Dewangan ", G. Sriram, A. Kumar, A. Mazumdar, A. Peketi, V. Mahale, S.S.C. Reddy, A. Babu \\ CSIR-National Institute of Oceanography, Dona Paula, Goa, 403004, India
}

\section{A R T I C L E I N F O}

\section{Keywords:}

Gas hydrates

Methane flares

Cold seeps

Shale tectonism

BSR

Seismic chimneys

\begin{abstract}
A B S T R A C T
Drilling/coring activities during NGHP-Expeditions 01 and 02 discovered significant gas hydrate deposits in the Krishna-Godavari (KG) basin, a proven petroliferous basin located along the eastern continental margin of India. Active and paleo-cold seeps are also reported from deep waters $(>1000 \mathrm{~m})$, indicating methane venting episodes in the KG basin. In the present study, we analyzed geophysical data acquired onboard RV Sindhu Sadhana to study the spatial distribution of gas flares in the KG offshore basin. Twenty-two gas flares were observed in water-column images at seafloor depths ranging from $638 \mathrm{~m}$ to $1960 \mathrm{~m}$. All flares except one are detected within the gas hydrate stability zone (GHSZ), which occurs beyond 700-720 m water depths. Most gas flares seem to terminate at these depths, indicating that the bubbles might be coated with a thin methane hydrate skin. Seabed sampling of flare regions shows the presence of chemosynthetic communities and shallow gas hydrates within 2-4 mbsf.

The spatial distribution of gas flares is not random and tends to align with the toe-thrust zones and shale diapiric mounds. These compressive structures formed due to shale tectonism in the KG basin have provided an environment conducive for the formation of gas hydrate deposits and gas flares/cold seeps. The analysis of highresolution seismic data across the flares shows the presence of seismic chimneys and faults, which facilitated migration of deep-seated fluid/gas through the GHSZ. Focused fluid flow along the fault zone and the perturbation of methane + seawater phase curve due to salinity increase owing to the continuous formation of methane hydrate are the most likely mechanisms to explain methane gas migration.
\end{abstract}

\section{Author contribution}

P. Dewangan: Conceptualization, Methodology, Validation and Writing - original draft, G. Sriram: Methodology, Visualization and data curations, A. Kumar: Software and data curations, A. Mazumdar: Investigation and Visualization, A. Peketi: Investigation and Visualization, V. Mahale: Software and data curations, S.S.C. Reddy: Visualization, A. Babu: Visualization.

\section{Introduction}

Methane seeps occur naturally over continental margins and have received broad attention from researchers working on methane budget, geohazards, gas hydrates and extreme ecosystems (Judd et al., 2002; Judd, 2003). Biogenic methane, a potent greenhouse gas, is produced in the subsurface by microbial degradation of organic matter, and it moves upward towards the seafloor either through diffusion or advection
(Archer et al., 2012). Methane can eventually seep from continental shelf regions, and a fraction of methane to the order of $18-48 \mathrm{Tg} / \mathrm{yr}$ reaches the atmosphere while the remaining fraction gets oxidized in the water column (Hornafius et al., 1999). The migration of methane gas through the unconsolidated sediments may also facilitate slumping/sliding in the slope regions of continental margins (Faure et al., 2006; Ramprasad et al., 2011). In deep-waters, methane gas is trapped into solid crystalline gas hydrates stable under high pressures and low temperatures (Sloan and Koh, 2007). Under some exceptional cases, methane may seep through the seafloor and leads to the proliferation of the chemosynthetic community and shallow occurrence of gas hydrate deposits. In high methane flux regions, almost $80 \%$ methane may escape the seafloor's biological filter and contribute $\sim 0.02 \mathrm{Gt}$ of methane to the ocean annually (Boetius and Wenzhöfer, 2013). In ultra-deepwater, a minor amount of abiogenic methane is produced by thermal degradation of organic matter by chemical processes operating in Earth's crust and upper mantle (Kvenvolden and Rogers, 2005).

\footnotetext{
* Corresponding author.

E-mail address: pdewangan@nio.org (P. Dewangan).
} 

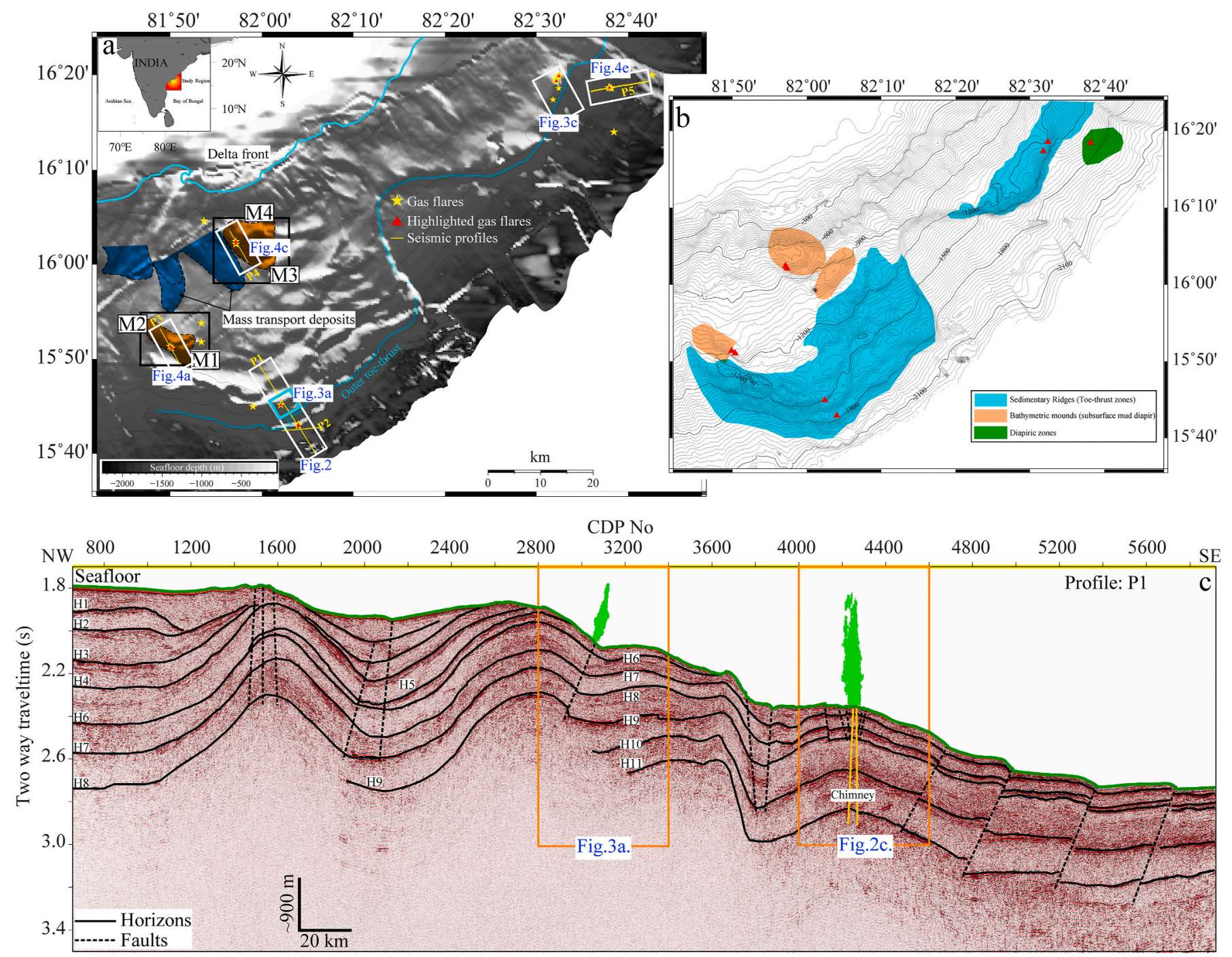

Fig. 1. (a) The swath bathymetry shows various geomorphic features in the Krishna-Godavari offshore basin (modified after Dewangan et al., 2010; Ramana et al., 2009; Ramprasad et al., 2011). The inset shows the study area in the Bay of Bengal. The stars represent the location of the gas flare observed in the water column imaging data acquired onboard $R / V$ Sindhu Sadhana and triangles show gas flares highlighted in the present study; (b) The contour map illustrating bathymetric mounds (M1 to M4 in Dewangan et al., 2010), sedimentary ridges and diapiric zones in the KG basin (after Dewangan et al., 2010; Mandal et al., 2014); (c) High-resolution air-gun seismic data (Profile: P1, the location marked by a solid line in Fig. 1a) across the active gas flares, where chemosynthetic community and shallow gas hydrates are recovered by seabed sampling (Mazumdar et al., 2019). The seafloor, subsurface seismic reflectors (H1 to H11) and toe-thrust fault system (dashed lines) are highlighted in the seismic section. The representative gas flares are superimposed on the seismic profile at the slope (CDPs 2800-3400; Fig. 3a) and rise of the toe - thrust fault system (CDPs 4000-4600). Solid vertical lines mark a subsurface chimney like feature.

Methane seeps have been reported from active and passive continental margins in various geological environments (Judd, 2003; Judd and Hovland, 2007). In active margins, fault systems provide a conducive environment for the movement of deep-seated fluid/gas to the seafloor. Several such seeps are reported from Nankai accretionary wedge (Henry et al., 2002; Le Pichon et al., 1987), Oregon subduction zone (Crutchley et al., 2013; Moore et al., 1990), Makran accretionary prism (Delisle et al., 2002), Southern California (Rudolph and Manga, 2010), Nankai trough (Tsunogai et al., 2012), Marmara Sea (Bayrakci et al., 2014; Dupré et al., 2015), Gulf of Izmit (Alpar, 1999), and Hikurangi margin (Greinert et al., 2010). In passive margins, other geological processes govern the spatial distribution of gas seeps. For example, salt tectonics control methane seeps in the lower Congo basin (Wenau et al., 2018), the Nile deep-sea fan (Dupré et al., 2010; Loncke and Mascle, 2004), Gulf of Mexico (Ruppel et al., 2005) and North Sea (Hovland and Judd, 1988); shear zones in the South-west Barent Sea (Foucher et al., 2010) and the west Svalbard margin (Plaza-Faverola et al., 2015); sediment slumping/sliding in Hikurangi margin (Faure et al., 2006) and offshore Oregon (Paull et al., 2002); stratigraphy control in Lake Baikal (Naudts et al., 2012).

Deep-water regions of the Krishna-Godavari (KG) offshore basin, Bay of Bengal, have been studied extensively to explore gas hydrate deposits (Dewangan et al., 2010; Ramana et al, 2006, 2009). The first drilling expedition NGHP-Exp-01 onboard JOIDES Resolution confirmed gas hydrate deposits in KG, Mahanadi and Andaman basins (Kumar et al., 2014). The second drilling expedition NGHP-Exp-02 confirmed gas hydrate deposits in sand-rich sediments of the KG basin (Kumar et al., 2019). Sediment sampling onboard $R / V$ Marion Dufresne confirmed paleo-methane venting events in the KG basin (Mazumdar et al., 2009; Badesab et al., 2017; Dewangan et al., 2013; Peketi et al., 2012). Active methane seeps and shallow methane hydrates have also been reported from the basin (Gullapalli et al., 2019; Mazumdar et al., 2019). However, the spatial distribution of methane seeps is mostly unknown. In the present study, we investigate for the first time the spatial distribution of methane seeps in the KG offshore basin using geophysical techniques, and attempt to understand the geological control on the distribution of 
Table 1

Location of gas flares observed in the Krishna-Godavari offshore basin, Bay of Bengal.

\begin{tabular}{lllll}
\hline Sr. & $\begin{array}{l}\text { Latitude (in deg. } \\
\text { North) }\end{array}$ & $\begin{array}{l}\text { Longitude (in deg. } \\
\text { East) }\end{array}$ & $\begin{array}{l}\text { Start Depth } \\
(\mathrm{m})\end{array}$ & $\begin{array}{l}\text { Terminate depth } \\
(\mathrm{m})\end{array}$ \\
\hline 1 & 16.08 & 81.90 & 638 & 488 \\
2 & 16.03 & 81.95 & 775 & 619 \\
3 & 16.04 & 81.95 & 746 & 515 \\
4 & 15.85 & 81.83 & 1050 & 719 \\
5 & 15.85 & 81.84 & 1083 & 486 \\
6 & 15.86 & 81.89 & 1158 & 800 \\
7 & 15.90 & 81.89 & 1073 & 745 \\
8 & 15.75 & 81.98 & 1328 & 954 \\
9 & 15.75 & 82.03 & 1475 & 715 \\
10 & 15.72 & 82.07 & 1734 & 750 \\
11 & 15.72 & 82.07 & 1756 & 746 \\
12 & 16.33 & 82.71 & 1960 & 740 \\
13 & 16.31 & 82.63 & 1667 & 730 \\
14 & 16.31 & 82.63 & 1671 & 714 \\
15 & 16.31 & 82.64 & 1652 & 710 \\
16 & 16.33 & 82.54 & 1196 & 729 \\
17 & 16.32 & 82.53 & 1125 & 656 \\
18 & 16.32 & 82.54 & 1162 & 758 \\
19 & 16.23 & 82.64 & 1907 & 840 \\
20 & 16.31 & 82.63 & 1653 & 776 \\
21 & 16.31 & 82.64 & 1666 & 989 \\
22 & 16.33 & 82.54 & 1165 & 739 \\
\hline & & & & \\
\hline
\end{tabular}

seeps.

\section{Geology of the study area}

Krishna-Godavari (KG) basin is a petroliferous pericratonic rift basin located along the eastern continental margin of India, which came into existence after the breakup of the Eastern Gondwana landmass around 130 ma ago (Powell et al., 1988; Ramana et al., 1994; Scotese et al., 1988). The Krishna and Godavari rivers deposit the bulk of sediments in the KG basin, and the thickness of sediments exceed $8 \mathrm{~km}$ in the offshore area (Prabhakar and Zutshi, 1993). General stratigraphy of the KG offshore basin shows sediments from the Early Cretaceous to Recent (Rao, 1993, 2001; Gupta, 2006; Bastia and Radhakrishna, 2012). Raghavpuram shale unit comprising organic-rich sediments overlain by interbedded sand and shale sequence was deposited during the Early Cretaceous. Chintalapalu shale was deposited during the Late Cretaceous, followed by Vadaparru formation, a major argillaceous facies deposited during the Paleocene to Eocene. Ravva formation representing interbedded sand-shale sequence was deposited during the Miocene to Pliocene. Godavari clay, the youngest stratigraphic unit, was deposited during the Quaternary.

Low-permeability smectite-rich clays were rapidly deposited during the Miocene and Paleocene; such a deposition mechanism leads to immobilization of pore fluids and displays abnormal formation pressure (Rao and Mani, 1993; Singha and Chatterjee, 2014). The presence of these deeply buried, over-pressured mobile shale strata causes tectonic instability and results in gravity-driven shale tectonism in KG offshore basin (Vijayalakshmi, 1988; Bastia, 2006; Choudhuri et al., 2010). Shale diapirism occurs due to the downward movement of thick sediment mass over mobile shale strata (Damuth, 1994). The regional seismic lines in the KG basin show extension regime in shelfal regions, translation and compression zones in the upper and lower slope regions (Bastia, 2006; Bastia and Radhakrishna, 2012). As observed in offshore bathymetry data, numerous mounds and ridges are considered to be the surficial imprint of shale tectonism (Dewangan et al., 2010).

\subsection{Geomorphology of the study area}

Rifting and drifting activities during the Gondwana landmass breakup have resulted in the formation of several horst and graben like structures oriented along NE-SW direction in the Krishna-Godavari onshore basin (Rao, 2001; Bastia and Nayak, 2006). Shelf-width is very narrow off the Krishna and Godavari rivers, and shelf-break occurs at a depth of $\sim 130 \mathrm{~m}$ (Murthy and Rao, 1990). Major geomorphic features in the KG offshore basin (Fig. 1a,b) are a) delta front between the outer shelf and upper slope incised with numerous valleys/canyons (Ramana et al., 2009); b) bathymetric mounds (M1-M4) formed due to deeply buried shale diapir and a sedimentary ridge (SR) controlled by toe thrust fault system (Dewangan et al., 2010); c) several mass transport deposits in the upper slope region associated with diapirism, faulting, and gas venting (Ramprasad et al., 2011). Mounds and sedimentary ridges are considered to be the surficial imprint of shale tectonism (Dewangan et al., 2010; Mandal et al., 2014). The mounds and ridges are often associated with fluid/gas migration features and deep-seated faults. The fault/fracture network acts as a conduit for fluid/gas passage from deep-seated reservoirs to shallow subsurface (Dewangan et al., 2011; Mishra et al., 2019).

\subsection{Occurrence of gas hydrates in the KG basin}

Gas hydrates occur abundantly in the KG basin, and widespread presence of bottom simulating reflector (BSR) is observed in seismic data in water depths of 700-2000 m (Dewangan et al., 2011; Mandal et al., 2014). The thickness of gas hydrate stability zone ranges from 40 to 250 m. During NGHP-Exp-01, methane hydrates are confirmed within a depth of $40-120$ mbsf in the KG basin at site NGHP-01-10. Past and active methane seepage events are deciphered from the presence of authigenic carbonates and chemosynthetic community (Joshi et al., 2014; Mazumdar et al, 2009, 2019).

\section{Data and methodology}

The data used in the present study were acquired by CSIR-NIO during the $45^{\text {th }}$ cruise of RV Sindhu Sadhana (SSD-045) in Jan-Feb 2018. About 165-line km of seismic data and $1650 \mathrm{~km}^{2}$ of multibeam bathymetric data were collected during the cruise in deep-water regions of the KG offshore basin, where the presence of gas hydrates has been confirmed by drilling/coring during NGHP-Exp-01 (Kumar et al., 2014).

Multiple high resolution seismic (HRS) data sets were acquired using different seismic sources like air-gun (G-gun; $60 \mathrm{cu}$. in.), sparker (400 tips), and sub-bottom profiler. For the seismic data collected with G-gun and sparker, the returned wavefield was recorded using a 48-channel streamer of $150 \mathrm{~m}$ length with a group interval of $3.125 \mathrm{~m}$. The shot interval was $8 \mathrm{~s}$ equivalent to $12.3 \mathrm{~m}$ travel distance, assuming an average cruise speed of 3 knots. G-gun's dominant frequency is $120 \mathrm{~Hz}$, and a six-fold CDP was achieved using this source-receiver geometry. The minimum source-receiver offset was set to $28 \mathrm{~m}$, and the sampling rate was chosen to be $2 \mathrm{~ms}$. The seismic data were loaded into a processing software "SeisSpace" to increase the signal-to-noise ratio and to produce high-quality seismic images for interpretation. The following processing sequence was applied: geometry was assigned to seismic data using the P1/90 format. Data were cleaned using low-cut $(40-60 \mathrm{~Hz})$ and high cut $(300-450 \mathrm{~Hz}$ ) filters to eliminate background noise. To increase the reflectors' continuity in the seismic section, swell and static corrections were applied to the data. An f-k filter was applied to the prestack data to improve the signal-to-noise ratio. Predictive deconvolution was used with a lag of $5 \mathrm{~ms}$ and an operator length of $100 \mathrm{~ms}$ to minimize the effect of bubble pulse and multiples. The limited offset of the seismic data does not permit velocity analysis; therefore, data were stacked after applying the normal-moveout correction assuming a constant velocity of $1500 \mathrm{~m} / \mathrm{s}$. Kirchhoff time migration was performed on the stacked data to position the reflectors accurately. The maximum depth of penetration is around $900 \mathrm{~m}$ below seabed with a vertical resolution of $5 \mathrm{~m}$.

A high-resolution geophysical survey was carried out using the stateof-the-art hull-mounted hydroacoustic equipment (ATLAS hydrographic, GmbH, Bremen, Germany) installed onboard RV Sindhu Sadhana. It 

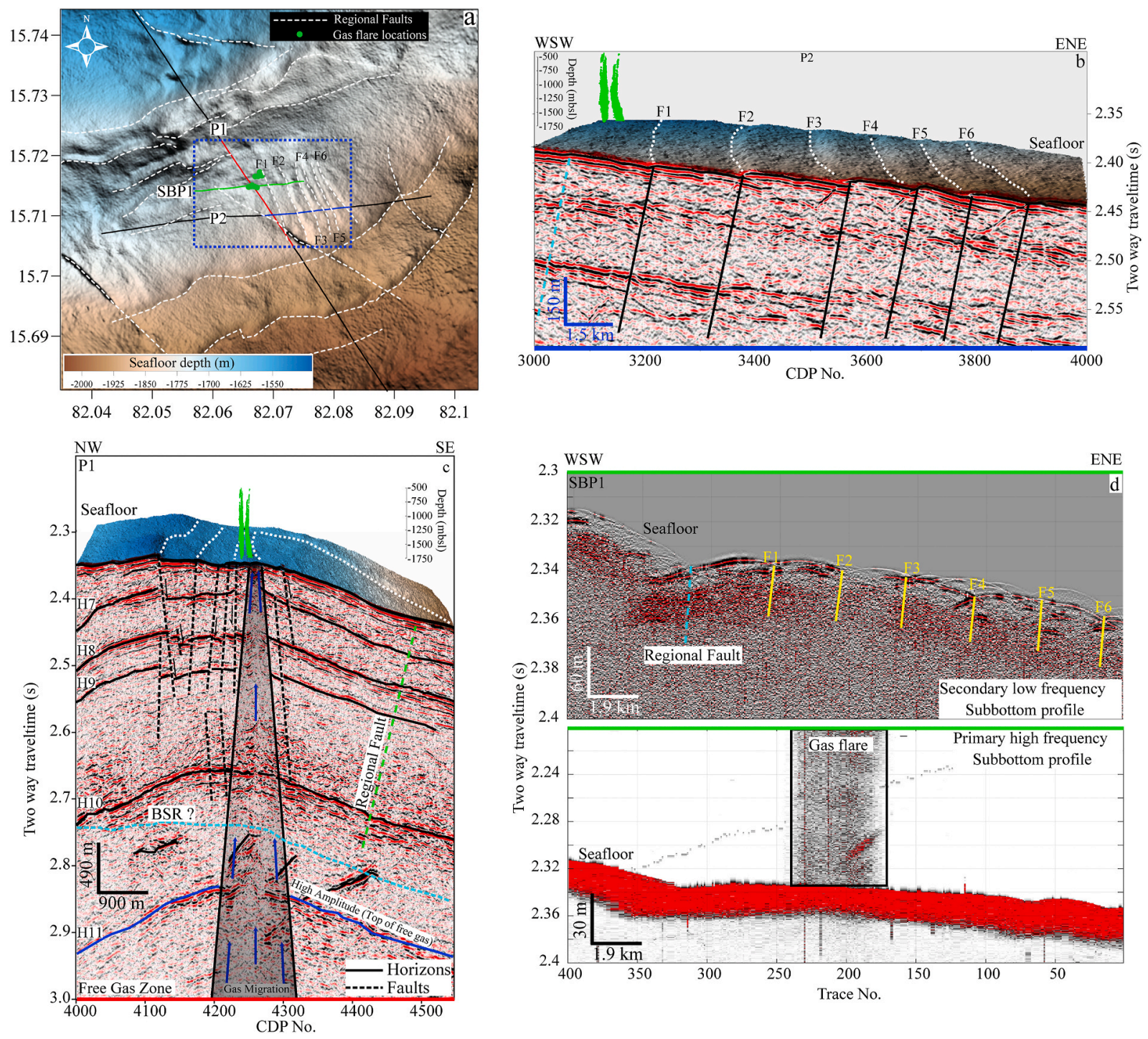

Fig. 2. (a) The detailed seafloor morphology map of the toe-thrust area along with the high-resolution air-gun seismic data (P1, P2), sub-bottom profiler (SBP) data showing primary high frequency (PHF) and secondary low frequency (SLF) components, location of gas flares (dots), regional faults (dashed lines) and NE-SW fault system (F1-F6) within a rectangular box (dotted lines). The two mutual perpendicular seismic profiles P1 (oriented in NW-SE direction) and P2 (oriented in WSWENE direction) are highlighted; (b) Seafloor (bathymetry surface) rendered across the seismic profile (P2) shows major fault system F1-F6 and their subsurface extension in seismic data (solid lines) and a regional fault (dashed line); (c) Seafloor (bathymetry) rendered across the seismic profile (P1) highlighting regional faults (dashed lines in bathymetry) and normal vertical faults (dashed lines on the seismic section). A subsurface chimney-like feature (solid lines), where the water column imaging shows gas flares, is also highlighted. The subsurface horizons (solid lines, H7 to H11), a feasible BSR (dashed line marked between TWT 2.7 and 2.8 s) and a regional toe-thrust fault from CDPs 4400 to 4500 (dashed line) are highlighted on the seismic section; (d) The low-frequency SBP data (SLF) show shallow faults (F1-F6), whereas high-frequency data (PHF) show the presence of gas flare from trace no. 165 to 240 in the water column.

includes the Hydrosweep DS-3 multibeam echosounder (MBES) system for acquiring swath bathymetry data and water-column imaging (Grant and Schreiber, 1990). The system was operated at a center frequency of $15.5 \mathrm{kHz}$ for full ocean depth. The depth uncertainties are about $1 \%$ of the water depth (Beyer et al., 2003). The data acquisition and post-processing of the bathymetric data were carried-out with Teledyne PDS software v4.3. Digital terrain models were generated with a grid resolution of $50 \mathrm{~m}$.

The Hydrosweep MBES (Hornafius et al., 1999) can also record each beam's water-column information spread out in a fan-shaped manner. The beam can capture acoustic scatterers like fish school, gas bubbles and plumes, and biomass layers in the water column. During the processing of water column image (WCI), gas bubbles can easily be traced from their roots on the seafloor and are often termed as gas flares. Once flares are identified, the data were cleaned for other reverberation noise using threshold filtering, speckle noise removal, or manual editing

\section{(Veloso et al., 2015).}

We obtained the shallow sedimentary information using the hullmounted ATLAS Teledyne Parasound P35 sub-bottom profiler (SBP) system, which was operated on the parametric mode by generating two acoustic frequencies at $18 \mathrm{kHz}$ and $23.5 \mathrm{kHz}$. The non-linear acoustic interferometry of these transmitted signals results in two secondary harmonics, i.e., $\sim 40 \mathrm{kHz}$ and $\sim 4 \mathrm{kHz}$. The primary advantage of using a parametric effect is that the resultant low-frequency signal can provide subsurface penetration. Also, the high-frequency signal can provide detailed information about the water column. Therefore, the data was recorded for $18 \mathrm{kHz}$ (primary high frequency: PHF) and $4 \mathrm{kHz}$ (secondary low frequency: SLF) frequencies. The parasound (PHF and SLF) data were processed using seismic Unix software with a bandpass filter $(200-6000 \mathrm{~Hz})$ and cleaned for noisy traces. 

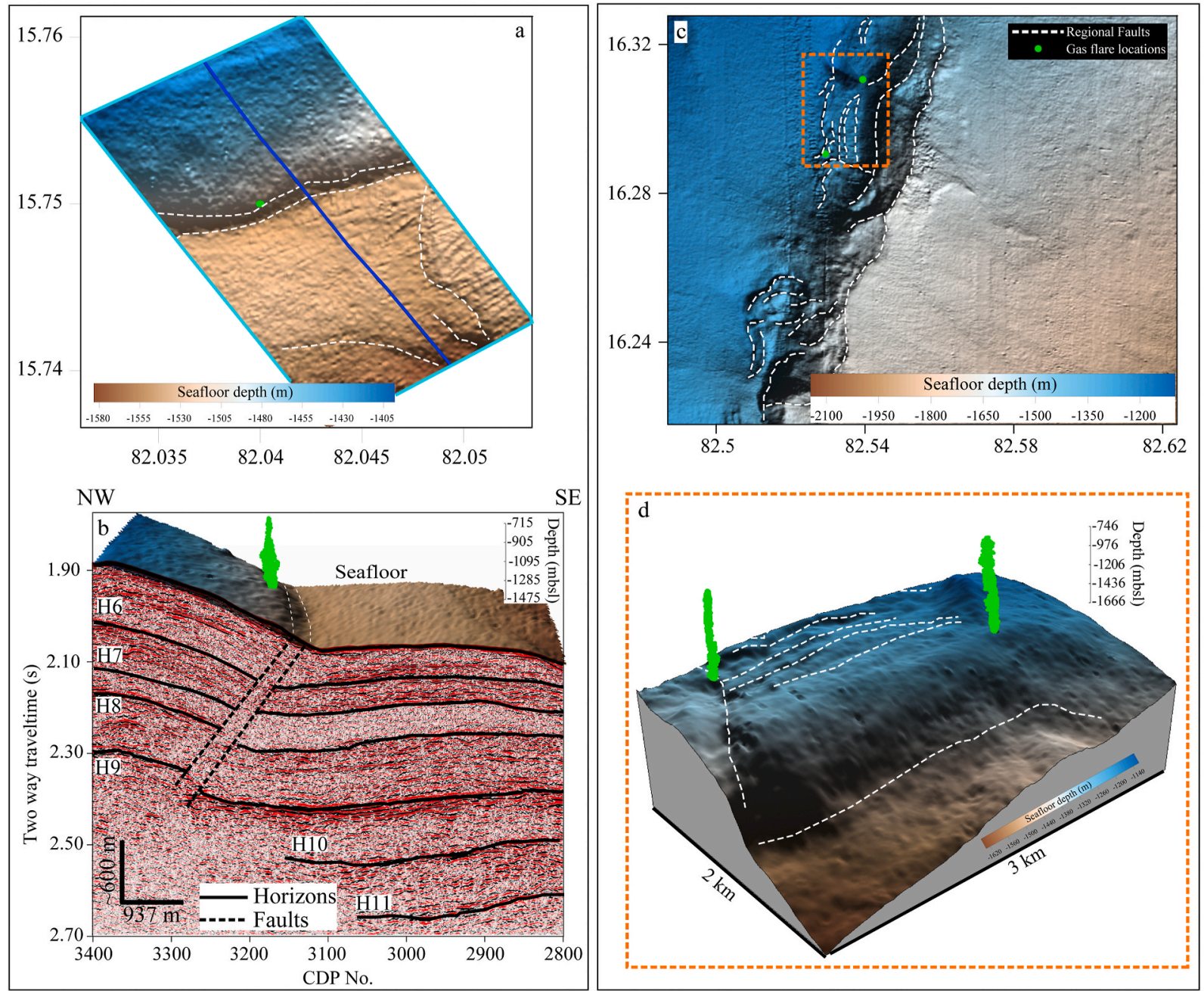

Fig. 3. (a) Detailed seafloor morphology map of the toe-thrust region highlighting seismic line (P1) and a major gas seep (dot); (b) Seafloor (bathymetry) rendered across the seismic profile (P1, CDPs: 2800-3400) highlighting a regional toe-thrust fault and the subsurface geological reflectors (solid lines, H6-H11); (c) Detailed seafloor morphology map of the toe-thrust area (NE part, Fig. 1a); (d) 3D seafloor bathymetry highlighting regional faults and associated gas flares identified from WCI.

\section{Results}

A $5000 \mathrm{~km}^{2}$ bathymetry mosaic illustrating various geomorphological features such as delta front, mass transport deposits, mounds and sedimentary ridges (Dewangan et al., 2010; Mandal et al., 2014; Mishra et al., 2019; Ramana et al., 2009; Ramprasad et al., 2011) in the KG offshore basin is shown in Fig. $1 \mathrm{a}$ and b. A regional seismic profile (Fig. 1c) shows several folded and faulted horizons (H1-H11) picked on the seismic section based on reflectors' amplitude. The surficial expression of folded/faulted strata appears as sedimentary ridges in the bathymetry mosaic. Water-column images (WCI) show twenty-two flare like anomalies, which are interpreted to be gas flares, and they seem to originate at seafloor depths ranging from 638 to $1960 \mathrm{~m}$ (Table 1). Two representative flares from the toe-thrust region are shown on the seismic section (Fig. 1c). In the present study, we broadly categorized the flare regions into three distinct zones: toe-thrust faults, buried shale diapir, and diapiric zone based on the seafloor morphology and subsurface structures. A detailed description of flares from these zones is as follows:

\subsection{Gas flares in toe-thrust regions of the KG basin}

Gas flares, a tell-tale signature of gas ebullition from the seabed (Judd and Hovland, 2007), were observed in the toe-thrust regions of the KG offshore basin (Figs. 1 and 2). During a multibeam survey, acoustic waves interact with gas bubbles and generate a strong backscattering signal due to large impedance contrast between water and gas bubbles; this signal detects the gas bubbles as flares. Most flares in the KG basin rose from surrounding water depths of $\sim 1750 \mathrm{~m}$ up to $\sim 750 \mathrm{~m}$. Detailed seafloor morphology map and a couple of air-gun profile and SBP data (PHF and SLF) acquired across the seep location are shown in Fig. 2. The toe-thrust region seems to be associated with extension-related normal faults (F1-F6) oriented in the NNW-SSE direction located atop the folded strata (Fig. 2a). Seafloor bathymetry is rendered across the seismic lines to highlight major faults (Fig. 2b). The seismic profile shows complex subsurface structures up to $3 \mathrm{~s}$ TWT with numerous faults (Fig. 2c). Several horizons are interpreted on the seismic profiles, which show discontinuity across the faults (Fig. $2 \mathrm{~b}$ and c). A chimney-like feature (from CDPs 4200 to 4320) is observed beneath the gas flare extending from a depth of $3.0 \mathrm{~s}$ TWT up to seafloor. Besides, a network of shallow normal faults developing from $2.6 \mathrm{~s}$ TWT up to seafloor is observed between CDPs 4050 and 4450.

We calculated the base of gas hydrate stability zone (GHSZ) to be $2095 \mathrm{~m}$ at $1800 \mathrm{~m}$ seafloor depth using the phase curve of methane + seawater (Miles, 1995), seafloor temperature derived from available CTD data and a mean geothermal gradient of $45{ }^{\circ} \mathrm{C} / \mathrm{km}$ (Mandal et al., 2014). This depth is converted into TWT (2.79 s) following the velocity trend of marine sediments in the KG basin (Mandal et al., 2014). Abrupt termination of high amplitude reflectors is observed around $2.79 \mathrm{~s}$ in 

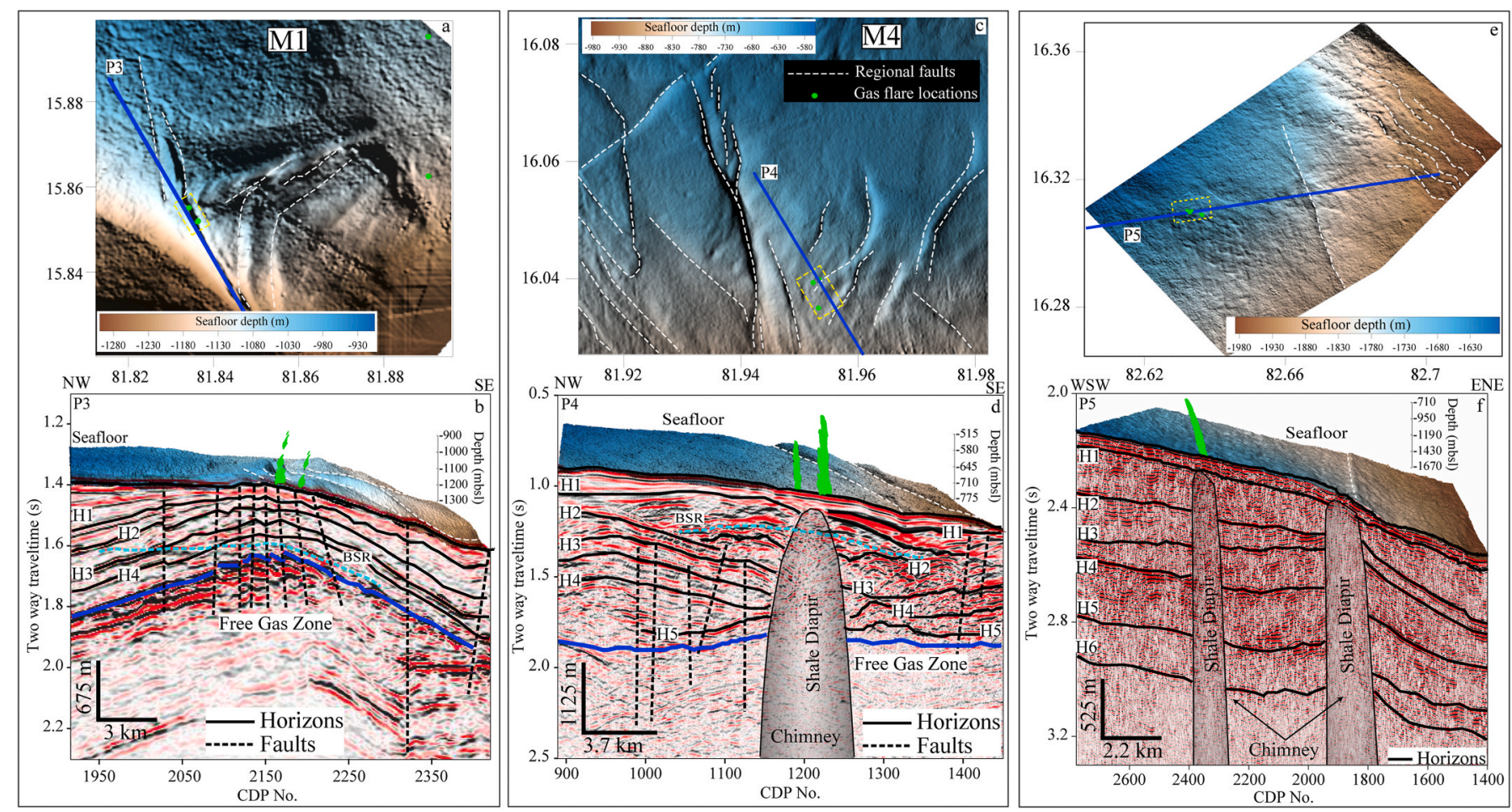

Fig. 4. (a) Detailed seafloor morphology map of bathymetric mound M1; Major fault systems (dashed lines) oriented along the north-south and east-west directions are marked on the seafloor. The gas flares identified from WCI are highlighted as dots; (b) High-resolution seismic data (P3) adopted from Mishra et al. (2019) show the subsurface information below the gas flares in mound M1; (c) Detailed seafloor morphology map of bathymetric mound M4 with major fault systems (dashed lines); (d) similar to (b) but show seismic data (P4) from mound M4 (after Mandal et al., 2014). The seismic profiles P4 show a chimney-like feature, which is associated with gas flares; (e) Seafloor bathymetry (Fig. 4e) of the diapiric mound (Fig. 1a) illustrating regional fault system oriented in the SW-NE and north-south directions and some gas flares (dots); (f) High-resolution air-gun seismic profile (P5) rendered with seafloor bathymetry shows a couple of chimneys and gas flares are identified over one of them.

seismic data (Fig. 2c), which may represent the base of GHSZ. In general, bottom simulating reflector (BSR) is not observed in high-resolution seismic data; however, abrupt termination of high amplitude reflectors is assumed to be a representation of BSR (Vanneste et al., 2001). Free gas zones are observed just below the BSR. The low-frequency SBP data (SLF in Fig. 2d) show shallow faults (F1-F6), which rupture the seafloor and a regional fault. In contrast, high-frequency SBP data (PHF in Fig. 2d) display the gas flare in the water column from trace nos. 165 to 240 .

Gas flares are also identified above the reverse toe-thrust fault, whose surface imprint is observed on the bathymetry map (Fig. 3a and b). The fault, characterized by a blanking zone, may act as a conduit for the migration of methane gas. A high-amplitude horizon at $2.4 \mathrm{~s}$ TWT may be associated with free gas as some of the deeper horizon cannot be traced from CDPs 3050 to 3300 owing to attenuation due to free gas.

\subsection{Gas flares over bathymetry mounds (M1 and M4) in the KG basin}

Gas flares were observed over prominent bathymetric mound (M1) in the KG offshore basin (Fig. 4a and b). Detailed seafloor morphology map shows numerous faults oriented along NNW-SSE and ENE-WSW directions similar to those observed from 3D seismic data (Mandal et al., 2014; Mishra et al., 2019; Riedel et al., 2010). The mound hosts site NGHP-01-10D, where gas hydrate and paleo-cold seep system were reported (Kumar et al., 2014; Mazumdar et al., 2009). The seismic profile (modified after Mishra et al., 2019) shows folded horizons (H1 to H4) with numerous extension-related normal faults. The gas flares, observed in the WCI, rose from surrounding water depth of $1030 \mathrm{~m}$ up to a depth of $750 \mathrm{~m}$ (Gullapalli et al., 2019). The seafloor varies from $1.4 \mathrm{~s}$ to $1.6 \mathrm{~s}$ TWT, and a BSR is observed between $1.6 \mathrm{~s}$ and $1.8 \mathrm{~s}$ TWT. A high-amplitude negative polarity horizon, interpreted as a free gas zone, is identified below the BSR from $1.7 \mathrm{~s}$ to $1.9 \mathrm{~s}$ TWT. Detailed analyses of seismic data confirm active fluid/gas migration along some faults (Dewangan et al., 2011; Gullapalli et al., 2019; Mishra et al., 2019; Sriram et al., 2013). Some addition flares are observed along the ENE-WSW oriented faults.

Gas flares were also observed over another bathymetric mound (M4) within water depths of $775 \mathrm{~m}$, which rose to a depth of $620 \mathrm{~m}$ (Fig. 4c and d). The bathymetry map shows numerous faults in the NW-SE, NESW, and NNW-SSE directions. The seismic data (Fig. 4d modified after Mandal et al., 2014) oriented in the NW-SE direction show folded and faulted horizons. The seafloor varies from $1.0 \mathrm{~s}$ to $1.2 \mathrm{~s}$ TWT, and a BSR is observed around $1.3 \mathrm{~s}$ from CDPs 1050 to 1320 . A chimney-like feature, probably representing a shale diaper, is observed between CDPs 1150 and 1250 (Fig. 4d) just beneath the flares. The chimney may have provided a conducive environment for the migration of deep-seated fluids.

\subsection{Gas flares near a shale diapir in the $K G$ offshore basin}

Gas flares were observed near a shale diapir in the KG offshore basin (Fig. 4e and f). Detailed seafloor morphology map of the diapir area (Fig. 4e) shows the location of gas flares, and a high-resolution air-gun seismic profile (Fig. 4f) shows geological structures related to shale diapir. The gas flares rose from a surrounding water depth of $1630 \mathrm{~m}$ to $\sim 750 \mathrm{~m}$. The seafloor is relatively flat with no significant relief; however, faults oriented in the NW-SE direction are observed in the northeastern part of the diapir region. A major fault oriented along the NNW-SSE direction (Fig. 4e) is identified in the central portion of the diapiric area. The seismic profile shows a chimney-like feature between CDPs 1750 and 1900, which is interpreted as a subsurface shale diapir. Subsurface horizons (H1 to H6) appear to be bent upward due to the shale diapir movement. No flares are observed atop the major subsurface 

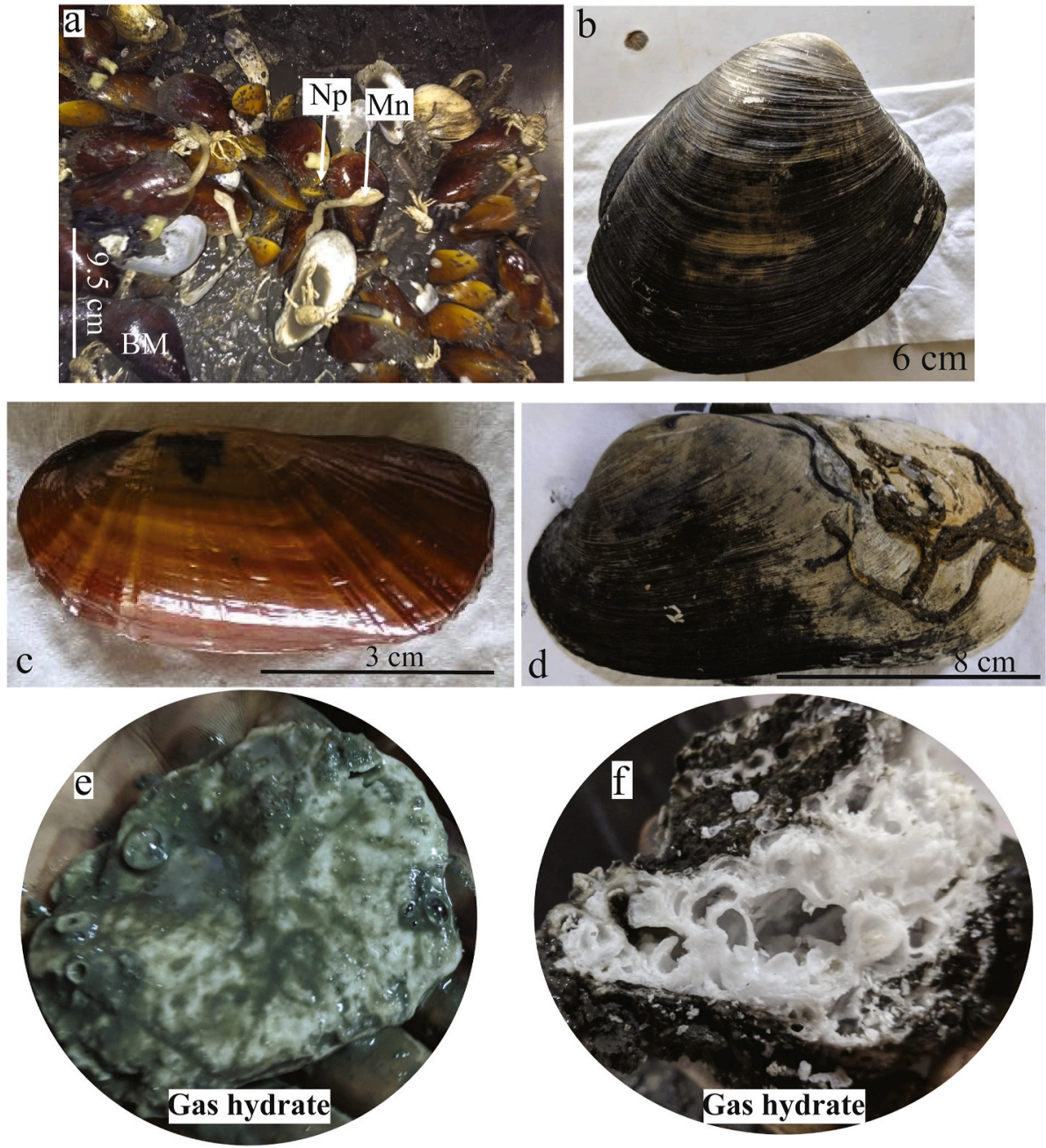

Fig. 5. (a) Shell cluster of chemosynthetic Bathymodiolus sp. in dark-sulfidic sediments recovered from spade cores. Goose barnacles (Neolepussp marked as $\mathrm{Np}$ ) are attached (white arrow marked) to the Bathymodiolus Shells. Squat lobsters belonging to the family Munidopsidae (Mn) are seen within the shell cluster; (B) Relict shell of Conchocele sp. (Conchocelesp. family: Thyasiridae); (c) Acharax sp. shell with soft body; (d) Relict shells ofCalyptogenasp. (family: Vesicomydae) with growth of worm tube; (e) shallow gas hydrate deposit recovered from the diapiric zone; (f) shallow hydrate recovered from the toe-thrust area. diapir; however, some flares are observed around CDP 2300, which may be linked with the presence of another chimney/shale diapir.

\subsection{Evidence of shallow gas hydrates and cold seep communities in the vicinity of flares}

A wide range of chemosynthetic and heterotrophic benthic organisms have been reported from the KG offshore basin (Mazumdar et al., 2019). While both live organisms and relict shells are observed from toe thrust regions of the KG Basin (Mazumdar et al., 2019), the present study reports the same from the diapiric zone (Fig. 5a-d). The live chemosynthetic organisms recorded from the diapiric region include bivalves belonging to the genus Bathymodiolus (family: Mytilidae), Acharax (family: Solemyidae) and gastropods belonging to the families Provannidae and Neritidae. Polychaetes belonging to the genus Sclerolinum and family Glyceridae are abundant at the toe thrust sites. The relict shell of bivalves belonging to the genus Conchocele (family: Thyasiridae) is also reported from diapiric sites. Heterotrophic communities belonging to the families Galatheidae and Munidopsidae (squat lobsters), the Ophiuroid, Amphiodia sp. (family: Amphiuridae), and Goose Barnacles belonging to the genus Neolepas (family: Eolepadidae) are recorded from these sites. In contrast to the toe thrust sites with a wide range of benthic organisms, the diaper sites are characterized by large relict shells of Calyptogena sp. (family: Vesicomydae) and Concocelae sp. (Thyasiridae). Live Acharax sp. was recorded from only one site in the diapiric region. In addition, shallow gravity cores acquired in this region show gas hydrates in the form of veins or nodules occurring within 2-3 $\mathrm{m}$ below the seafloor (Fig. 5e and f).

\section{Discussions}

\subsection{Geophysical evidences of gas migration through the seafloor}

Water column images show twenty-two gas flares from the continental slope regions of KG basin at water depths ranging from 638 to $1960 \mathrm{~m}$ (Figs. 1-4; Table 1), indicating fluid/gas migration across the seafloor. Sediment samples from flare locations show chemosynthetic communities and shallow methane hydrates (Mazumdar et al., 2019, Fig. 5). The presence of hydrates suggests that the primary constitution of gas flares is methane. In addition to water column images, the flares are also observed in the PHF data; however, they are not detected in other low-frequency seismic data like sparker, G-gun and $12 \mathrm{kHz}$ single beam echosounder. The density of methane gas is significantly lower than that of seawater, resulting in a large impedance (a product of density and velocity) contrast. Strong backscattering is generated from this contrast and facilitates the detection of gas bubbles by multibeam echosounders (Greinert et al., 2006). Detection of gas flares also depends on the bubbles' resonance frequency, which varies with the radius and depth of the bubble (Guinasso and Schink, 1973; Vagle and Farmer, 1992). The dominant frequencies of sparker, G-gun and $12 \mathrm{kHz}$ echosounder might not be suitable for detecting gas flares at these water depths.

A significant amount of biogenic methane is produced in marine sediments below the sulfate-methane transition zone via $\mathrm{CO}_{2}$ reduction 


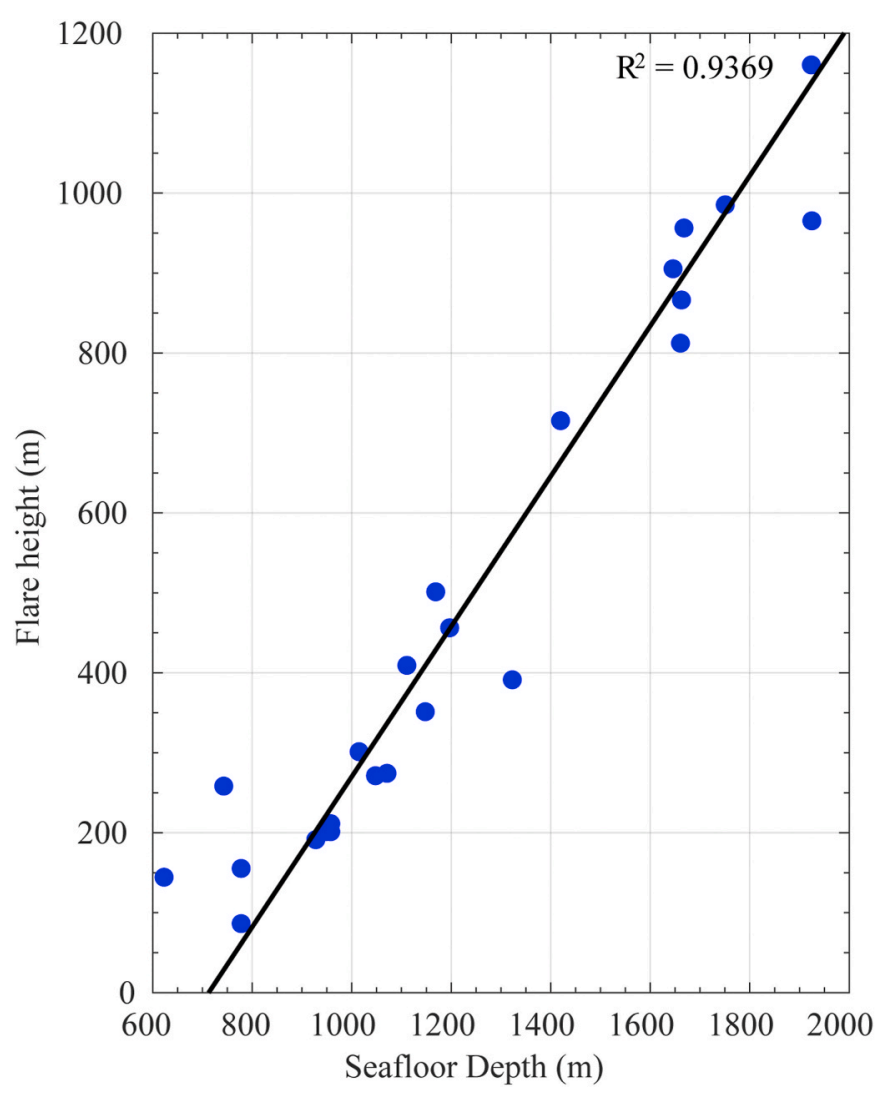

Fig. 6. Cross plot between seafloor depth and height of gas flares showing excellent correlation with an $\mathrm{R}^{2}$ coefficient of 0.9369 .

in the presence of methanogenesis archaea (Reeburgh, 2007). Methane in excess of solubility limit occurs as bubbles, which rise due to positive buoyancy and may even rupture the seafloor through faults/fractures or other permeable pathways. As bubbles rise, methane dissolves in the water column. The dissolution rate depends primarily on bubble size and surface contaminants like oil/gas hydrate on the bubble (McGinnis et al., 2006). The map of GHSZ suggests that hydrates are stable beyond $700-720$ m water depths in the KG basin (Rastogi et al., 1999). The observed flares lie within the GHSZ; therefore, methane bubbles are expected to be coated with a hydrate skin that will significantly decrease the rate of methane dissolution. The protection of bubbles due to hydrate skin is primarily responsible for the occurrence of tall flares in the Guyamas basin (Merewether et al., 1985), Hydrate Ridge (Heeschen et al., 2003), the Black Sea (Greinert et al., 2006), offshore West Svalbard (Bünz et al., 2012), Opouawe Bank, Cook Strait, New Zealand (Law et al., 2010), Gulf of Mexico (Leifer and MacDonald, 2003; Römer et al., 2019), Nile Deep-sea fan (Römer et al., 2014), Sea of Okhotsk (Obzhirov et al., 2004), Lower Congo basin (Wenau et al., 2015) and North Sea (Hovland, 2007). In the present study, we observe that the height of flare is dependent on the seafloor depth, and most of the bubbles rise to 700 m, i.e., up to the boundary of GHSZ (Fig. 6). As the bubble crosses the GHSZ, hydrate coating dissociates, and methane dissolves rapidly, leading to abrupt truncation of gas flare at the boundary of GHSZ. A similar fate of bubbles was reported from Monterey Bay (Rehder et al., 2002).

\subsection{Methane emission and formation of chemosynthetic ecosystem}

The proliferation of chemosynthetic community is observed near gas flares. Hydrogen sulfide $\left(\mathrm{H}_{2} \mathrm{~S}\right)$ and methane $\left(\mathrm{CH}_{4}\right)$ in the sediment porefluid fuel the sustenance of cold-seep ecosystems. High methane concentrations within the sediments are responsible for driving intense sulfate reduction in the sediments via anaerobic oxidation of methane (AOM: Knittel and Boetius, 2009) pathway as represented by the equation,

$\mathrm{SO}_{4}{ }^{2-}+\mathrm{CH}_{4} \rightarrow \mathrm{HCO}_{3}{ }^{-}+\mathrm{HS}^{-}+\mathrm{H}_{2} \mathrm{O}$

The sulfide and methanotrophic bacterial load within bacteriocyte cells in the body cavities of the chemosynthetic organisms carry out the oxidation of the $\mathrm{H}_{2} \mathrm{~S}$ and $\mathrm{CH}_{4}$ imbibed by the organism from the ambient sediment pore-fluid (Duperron et al., 2013). The energy produced via the oxidation process is used for the growth of the organisms. On the other hand, the associated heterotrophs consume chemosynthetic organisms, algal mats, or other organic detritus for survival. The average $\delta^{13} \mathrm{C}_{\mathrm{CH} 4}(-73.7 \pm 0.7 \%$ o VPDB $)$ of the methane hydrates from the studied cold seep sites (Mazumdar et al., 2019) indicate biogenic methane source and the hydrates are typically fractured filling types. At the diapir region (Fig. 5b,d), the abundance of large relict shells of chemosynthetic (thyrotropic) clams of Callyptogena $s p$. shells suggests reduced flux of hydrogen sulfide across the sediment-water interface likely caused by depleted vertical methane flux. The drop in methane flux may indicate the plugging of an active fault system, possibly due to the growth of massive gas hydrate or carbonate crust.

\subsection{Structural control on the occurrence of methane seeps}

We observed that prevalent shale tectonism in the KG basin governs gas flares' spatial distribution in offshore regions. The toe-thrust zones (Figs. 1-3), identified as sedimentary ridges on bathymetry data, provide a favorable compressional regime for the migration of fluid/gas. The bathymetric mounds (Fig. 4a-d) and diapiric zone (Fig. 4e and f), representing shale diapirism regions, also provide a conducive environment for methane seep. In the present study, we imaged a couple of subsurface shale diapirs at $1800 \mathrm{~m}$ using HRS data (Fig. 4f), and four gas flares are observed over one of the diapirs. Sediment sampling in toethrust and diapiric regions show the presence of chemosynthetic communities and shallow hydrate deposits within 2-3 mbsf (Fig. 5; Mazumdar et al., 2019). It is interesting to note that the diapiric and toe-thrust regions favor the formation of gas hydrate in the KG basin (Dewangan et al., 2010) and also provide a conducive environment for the evolution of gas flares and active cold seep.

The compressional forces resulting from shale tectonism causes folding and faulting of overburden sediments. In some cases, the overpressured strata are mobilized as shale diapirs. Faults generated from the movement of shale diapir may facilitate the migration of gas from deep-seated reservoirs. The focused fluid flow toward the crest of anticline may yield a local overpressured regime, which may develop an extensive fault/fracture system through hydro-fracturing (Frederick and Buffett, 2011). Such a mechanism is proposed for the genesis of methane seepage at hydrate ridge, offshore Oregon (Crutchley et al., 2013), the Central and Cinarcik basins, Sea of Marmara (Dupré et al., 2015) and Hikurangi margin, offshore NewZealand (Law et al., 2010).

Several studies worldwide show structural and/or stratigraphic control on gas hydrate and methane flares (Hovland et al., 2012). For example, giant pockmark off West Africa (Olu-Le Roy et al., 2007), Central Nile deep sea fan (Römer et al., 2014), offshore Korea (Haacke et al., 2009), the Calabrian accretionary prism, Ionian Sea (Loher et al., 2018), mud volcanoes in the Black sea (Bohrmann et al., 2003), Southwest Barents sea (Chand et al., 2014), Sea of Marmara (Dupré et al., 2015), Sea of Okhotsk (Obzhirov et al., 2004), Black Ridge diapir (Brothers et al., 2013; Paull et al., 1995), Vestnesa Ridge offshore Svalbard (Bünz et al., 2012), hydrate ridge offshore Oregon (Crutchley et al., 2013), eastern Nankai accretionary margin (Henry et al., 2002), Hikurangi margin, offshore NewZealand (Krabbenhoeft et al., 2013; Law et al., 2010), Nile deep-sea fan (Loncke and Mascle, 2004), Tommeliten in the North Sea (Schneider von Deimling et al., 2011), and Lower Congo basin (Wenau et al., 2015). Therefore, we propose that the deformation 


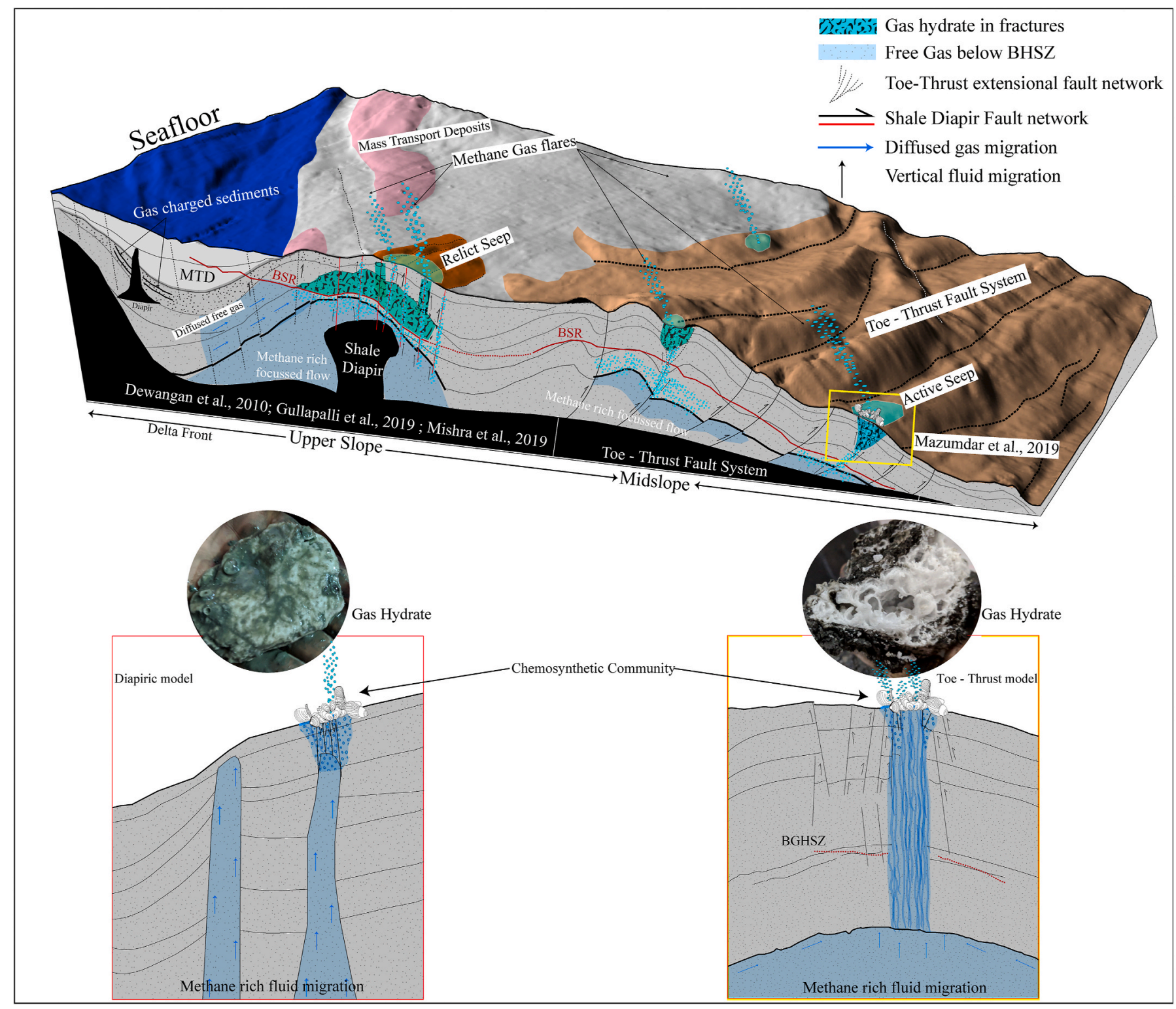

Fig. 7. Conceptual model illustrating the relationship between geological environments and gas flares. Various shale tectonism elements, like shale diapir and toethrust fault systems, provide a environment conducive for sub-surface fluid migration through deep-rooted faults. The mid-slope region is associated with subsurface shale diapirs, which are manifested in bathymetry data as mounds. Likewise, the lower-slope area associated with toe-thrust related folded and faulted sediments are displayed as sedimentary ridges. Seabed sampling of flare regions shows diverse chemosynthetic communities and shallow gas hydrates within 2-3 mbsf.

structures formed due to shale tectonism govern the spatial distribution of gas flares in the deeper regions of KG basin.

Widespread seepages are reported near the boundary of GHSZ from the Arctic sea (Andreassen et al., 2017; Westbrook et al., 2009), the northern US Atlantic margin (Skarke et al., 2014), Cascadia margin (Johnson et al., 2015), Amazon deep-sea fan (Ketzer et al., 2018) and Black Sea (Naudts et al., 2006) either due to increase in bottom water temperature or increase in salinity. In contrast, isolated seeps are observed along the boundary of GHSZ in the KG basin. Therefore, the bottom water temperature and salinity might be stable in the deep waters of KG basin. However, an extensive survey is required to confirm other gas seepages along the boundary of GHSZ. A conceptual figure explaining various shale tectonism processes governing gas migration in the KG basin is shown in Fig. 7.

\subsection{Role of seismic chimneys/faults in the migration of methane gas}

Methane migration in gaseous form should be arrested in GHSZ due to gas hydrates; however, we observed twenty-one gas flares within GHSZ from the KG basin. In the toe-thrust region, HRS data analysis suggests a chimney-like structure in the subsurface beneath the gas flares (Fig. 2c). Signatures associated with BSR are observed around $2.79 \mathrm{~s}$ TWT. Some high amplitude zones, which may be related to free gas, are detected below the BSR. Therefore, seismic chimney provides a conducive pathway for the migration of deep-seated fluid/gas through GHSZ.

Bathymetric mounds (M1 and M4 in Fig. 4a-d) and diapiric zone (Fig. 4e-f) are also associated with gas flares. The HRS data show intensive faulting, and acoustic blanking beneath some flares. The analysis of 3D seismic data from the KG basin suggests two distinct fault groups oriented in NNW-SSE and ENE-WSW directions related to passive tectonism (Mandal et al., 2014;Mishra et al., 2019; Riedel et al., 2010). Further, the AVO analysis of 2D seismic data indicates gas migration through active faults (Gullapalli et al., 2019). The velocity model derived from 3D seismic data suggests that gas is being supplied from a deep-seated reservoir (Mishra et al., 2019). Worldwide, gas flares 
associated with cold seeps are reported in the vicinity of intrusive structures like a shale/salt diapir (Hovland and Curzi, 1989; Hovland, 1990; Lüdmann and Wong, 2003; Römer et al., 2012) or mud volcanoes (Foucher et al., 2010; Gaynanov et al., 1998; Greinert et al., 2006; Loher et al., 2018; Loncke and Mascle, 2004; Milkov et al., 2003; Pape et al., 2011; Paull et al., 2008). Drilling/coring data acquired during NGHP-Exp-01 in the KG basin shows that overburden sediments comprise of low-permeability clay. The clay sediments cannot support vertical migration of gas; therefore, geological structures like faults/fractures (e.g., Dupré et al., 2015), seismic chimneys/pipes (Løseth et al., 2011) or high permeable strata (Crutchley et al., 2010) are required for gas migration. In the present study, we show the faults/chimneys formed due to shale tectonism are responsible for mobilizing deep-seated gas to the seafloor.

\subsection{Mechanism of methane migration through the GHSZ}

The present study established the migration of methane through GHSZ via seismic chimney/fault zones. The methane can migrate through GHSZ by modifying the methane + seawater phase curve due to an increase in temperature and salinity or decrease in pressure. The perturbation of the phase curve due to high-temperature deep-seated fluids is observed in the Cascadia margin (Wood et al., 2002) and Hikurangi margin (Pecher et al., 2010). However, such a mechanism is not likely in the KG basin as seismic data analysis does not reveal a significant upwarping of BSR (Dewangan et al., 2011; Mandal et al., 2014). Alternatively, the perturbation in salinity due to salt diapir or evaporate deposits may cause local upwarping of the base of GHSZ. However, salt deposits are not observed in the stratigraphy of KG basin; therefore, such a mechanism is not feasible. Most of the gas flares are observed in ultra-deep waters $(>1000 \mathrm{~m})$. A significant fall in sea level, like the one observed during last glacial maximum (Lambeck et al., 2014), cannot destabilize the seafloor's gas hydrates; therefore, pressure drop due to the fall of sea level cannot explain the observed gas flares.

Other mechanisms to explain the methane migration through GHSZ are short-range methane diffusion, focused fluid flow (methane in dissolved phase) and advection of free methane gas (Meyer et al, 2018, 2020; You and Flemings, 2018; You et al., 2019). The short-range methane diffusion (Malinverno and Goldberg, 2015) can explain the migration locally, but it fails to explain the methane migration throughout the GHSZ. Focused fluid flow is a mechanism in which methane migrates in the dissolved phase, leading to excess pore pressure beneath structural high and induce hydro-fracturing generating fault/fracture network (Frederick and Buffett, 2011). Another possibility is the migration of methane as a gaseous phase through the fault system (Haacke et al., 2009; Liu and Flemings, 2007). In regions of high methane flux, the continuous formation of hydrates increases the salinity of surrounding pore water; thereby, perturbing the methane + seawater phase curve and supporting the coexistence of all three phases (gas, hydrate, and liquid). Further, the formation of a hydrate shell around the advancing gas front may limit methane diffusion allowing the migration of methane gas through GHSZ (Meyer et al., 2020). The most likely mechanisms for gas flares in the KG basin might be the focused fluid flow or the local perturbation of GHSZ due to increased salinity owing to hydrate formation. However, additional geophysical/geochemical investigations are warranted to resolve the mechanism.

\section{Conclusions}

Geophysical investigations show twenty-two flares in the KG basin at water depths ranging from $638 \mathrm{~m}$ to $1960 \mathrm{~m}$. All flares except one originate at depths, where the gas hydrates are stable. Majority of flares rose from the surrounding seafloor to a depth of 700-720 m, which represents the boundary of the GHSZ. The following observations are noted for the gas flares in the KG basin:
1) Gas flares are only detected in high-frequency echosounders ( $>14$ $\mathrm{kHz}$ ) and are not observed in low-frequency SBP, air-gun and sparker datasets.

2) Structural elements of shale tectonism, like toe-thrust faults and shale diapirs, govern the spatial distribution of gas flares.

3) Sediment sampling from the flare regions shows diverse chemosynthetic communities and shallow methane hydrate within 2-4 mbsf.

4) Seismic chimneys and fault/fracture system provide a conducive environment for the migration of deep-seated gas up to the seafloor.

5) Focused fluid flow and salinity increase due to hydrate formation are likely mechanisms for methane migration through GHSZ.

\section{Declaration of competing interest}

The authors declare that they have no known competing financial interests or personal relationships that could have appeared to influence the work reported in this paper.

\section{Acknowledgments}

We thank the Director, CSIR-National Institute of Oceanography (NIO) for supporting the gas hydrate research program at CSIR-NIO. We also extend our sincere thanks to the crew members, ship cell team (Mr. G. P. Naik) and the survey team to provide valuable support onboard $R$ / $V$ Sindhu Sadhana. Dr. Sriram Gullapalli would like to thank the science and engineering research board (SERB) for providing financial support through an award of the Early Career Research Award (Ref. No: ECR/ 2018/000089/EAS). The work was performed under the CSIR MLP1703 program, and the contribution no. is 6615 .

\section{Appendix A. Supplementary data}

Supplementary data to this article can be found online at https://doi. org/10.1016/j.marpetgeo.2020.104783.

\section{References}

Alpar, B., 1999. Underwater signatures of the kocaeli earthquake (august $17^{\text {th }} 1999$ ). Turk. J. Mar. Sci. 5 (3), 111-130.

Andreassen, K., Hubbard, A., Winsborrow, M., Patton, H., Vadakkepuliyambatta, S., Plaza-Faverola, A., Gudlaugsson, E., Serov, P., Deryabin, A., Mattingsdal, R.,

Mienert, J., Bünz, S., 2017. Massive blow-out craters formed by hydrate-controlled methane expulsion from the Arctic seafloor. Science 356, 948-953.

Archer, D.E., Buffett, B.A., McGuire, P.C., 2012. A two-dimensional model of the passive coastal margin deep sedimentary carbon and methane cycles. Biogeosciences 9 , 2859-2878. https://doi.org/10.5194/bg-9-2859-2012.

Badesab, F., Dewangan, P., Usapkar, A., Kocherla, M., Peketi, A., Mohite, K., Sangode, S. J., Deenadayalan, K., 2017. Controls on evolution of gas-hydrate system in the Krishna-Godavari basin, offshore India. G-cubed 18 (1), 52-74.

Bastia, R., 2006. An overview of Indian sedimentary basins with special focus on emerging east coast deep-water frontiers. Lead. Edge 25, 818-829.

Bastia, R., Nayak, P., 2006. Tectonostratigraphy and depositional patterns in Krishna offshore basin, Bay of Bengal. Lead. Edge 25 (7), 839-845.

Bastia, R., Radhakrishna, M., 2012. Basin Evolution and Petroleum Prospectivity of the Continental Margins of India, Developments in Petroleum Science, vol. 59. Elsevier, Amsterdam.

Bayrakci, G., Scalabrin, C., Dupré, S., Leblond, I., Tary, J.-B., Lanteri, N., Augustin, J.-M., Berger, L., Cros, E., Ogor, A., Tsabaris, C., Lescanne, M., Géli, L., 2014. Acoustic monitoring of gas emissions from the seafloor. Part II: a case study from the Sea of Marmara. Mar. Geophys. Res. 35, 211-229.

Beyer, A., Schenke, H.W., Klenke, M., Niederjasper, F., 2003. High resolution bathymetry of the eastern slope of the Porcupine Seabight. Mar. Geol. 198, 27-54. https://doi. org/10.1016/S0025-3227(03)00093-8.

Boetius, A., Wenzhöfer, F., 2013. Seafloor oxygen consumption fuelled by methane from cold seeps. Nat. Geosci. 6, 725-734.

Bohrmann, G., Ivanov, M., Foucher, J.-P., Spiess, V., Bialas, J., Greinert, J., Weinrebe, W., Abegg, F., Aloisi, G., Artemov, Y., Blinova, V., Drews, M., Heidersdorf, F., Krabbenhöft, A., Klaucke, I., Krastel, S., Leder, T., Polikarpov, I., Saburova, M., Schmale, O., Seifert, R., Volkonskaya, A., Zillmer, M., 2003. Mud volcanoes and gas hydrates in the Black Sea: new data from Dvurechenskii and Odessa mud volcanoes. Geo Mar. Lett. 23, 239-249.

Brothers, L.L., Van Dover, C.L., German, C.R., Kaiser, C.L., Yoerger, D.R., Ruppel, C.D., Lobecker, E., Skarke, A.D., Wagner, J.K.S., 2013. Evidence for extensive methane venting on the southeastern U.S. Atlantic margin. Geology 41, 807-810. https://doi. org/10.1130/G34217.1. 
Bünz, S., Polyanov, S., Vadakkepuliyambatta, S., Consolaro, C., Mienert, J., 2012. Active gas venting through hydrate-bearing sediments on the Vestnesa Ridge. offshore WSvalbard. Mar. Geol. 332-334, 189-197.

Chand, S., Knies, J., Baranwal, S., Jensen, H., Klug, M., 2014. Structural and stratigraphic controls on subsurface fluid flow at the Veslemøy High, SW Barents Sea. Mar. Petrol. Geol. 57, 494-508.

Choudhuri, M., Guha, D., Dutta, A., Sinha, S., Sinha, N., 2010. Spatiotemporal variations and kinematics of shale mobility in the Krishna-Godavari Basin. Indiana 91-109. https://doi.org/10.1306/13231310M933420.

Crutchley, G.J., Pecher, I.A., Gorman, A.R., Henrys, S.A., Greinert, J., 2010. Seismic imaging of gas conduits beneath seafloor seep sites in a shallow marine gas hydrate province, Hikurangi Margin, New Zealand. Mar. Geol. 272, 114-126.

Crutchley, G.J., Berndt, C., Geiger, S., Klaeschen, D., Papenberg, C., Klaucke, I., Hornbach, M.J., Bangs, N.L.B., Maier, C., 2013. Drivers of focused fluid flow and methane seepage at south Hydrate Ridge. offshore Oregon, USA. Geology 41 (5), $551-554$.

Damuth, J.E., 1994. Neogene gravity tectonics and depositional processes on the deep Niger Delta continental margin. Mar. Petrol. Geol. 11, 320-346.

Delisle, G., von Rad, U., Andruleit, H., Von Daniels, C., Tabrez, A., Inam, A., 2002. Active mud volcanoes on- and offshore eastern Makran, Pakistan. Int. J. Earth Sci. 91, 93-110.

Dewangan, P., Ramprasad, T., Ramana, M.V., Mazumdar, A., Desa, M., Badesab, F.K., 2010. Seabed morphology and gas venting features in the continental slope region of Krishna-Godavari basin, Bay of Bengal: implications in gas-hydrate exploration. Mar. Petrol. Geol. 27, 1628-1641.

Dewangan, P., Sriram, G., Ramprasad, T., Ramana, M.V., Jaiswal, P., 2011. Fault system and thermal regime in the vicinity of site NGHP-01-10, Krishna-Godavari basin, Bay of Bengal. Mar. Petrol. Geol. 28 (10), 1899-1914.

Dewangan, P., Basavaiah, N., Badesab, F.K., Usapkar, A., Mazumdar, A., Joshi, R., Ramprasad, T., 2013. Diagenesis of magnetic minerals in a gas hydrate/cold seep environment off the Krishna-Godavari basin, Bay of Bengal. Mar. Geol. 340, 57-70.

Duperron, S., Gaudron, S.M., Rodrigues, C.F., Cunha, M.R., Decker, C., Olu, K., 2013. An overview of chemosynthetic symbioses in bivalves from the North Atlantic and Mediterranean Sea. Biogeosciences 10, 3241-3267.

Dupré, S., Woodside, J., Klaucke, I., Mascle, J., Foucher, J.-P., 2010. Widespread active seepage activity on the Nile Deep Sea Fan (offshore Egypt) revealed by highdefinition geophysical imagery. Mar. Geol. 275, 1-19.

Dupré, S., Scalabrin, C., Grall, C., Augustin, J.-M., Henry, P., Şengör, A.M.C., Görür, N., Çağatay, M.N., Géli, L., 2015. Tectonic and sedimentary controls on widespread gas emissions in the Sea of Marmara: results from systematic, shipborne multibeam echo sounder water column imaging. J. Geophys. Res. 120, 2891-2912.

Faure, K., Greinert, J., Pecher, I.A., Graham, I.J., Massoth, G.J., de Ronde, C.E.J., Wright, I.C., Baker, E.T., Olson, E.J., 2006. Methane seepage and its relation to slumping and gas hydrate at the Hikurangi margin, New Zealand. N. Z. J. Geol. Geophys. 49, 503-516.

Foucher, J.-P., Dupré, S., Scalabrin, C., Feseker, T., Harmegnies, F., Nouzé, H., 2010. Changes in seabed morphology, mud temperature and free gas venting at the Håkon Mosby mud volcano, offshore northern Norway, over the time period 2003-2006. Geo Mar. Lett. 30, 157-167.

Frederick, J.M., Buffett, B.A., 2011. Topography- and fracture-driven fluid focusing in layered ocean sediments. Geophys. Res. Lett. 38 (8), 1-5.

Gaynanov, V.G., Bouriak, S.V., Ivanov, M.K., 1998. Seismic evidence for gas accumulation related to the area of mud volcanism in the deep Black Sea. Geo Mar. Lett. 18, 139-145. https://doi.org/10.1007/s003670050061.

Grant, J.A., Schreiber, R., 1990. Modern swathe sounding and sub-bottom profiling technology for research applications. Mar. Geophys. Res. 12, 9-11.

Greinert, J., Artemov, Y., Egorov, V., De Batist, M., McGinnis, D., 2006. 1300-m-high rising bubbles from mud volcanoes at $2080 \mathrm{~m}$ in the Black Sea: hydroacoustic characteristics and temporal variability. Earth Planet Sci. Lett. 244, 1-15.

Greinert, J., Lewis, K.B., Bialas, J., Pecher, I.A., Rowden, A., Bowden, D.A., De Batist, M., Linke, P., 2010. Methane seepage along the Hikurangi Margin, New Zealand: overview of studies in 2006 and 2007 and new evidence from visual, bathymetric and hydroacoustic investigations. Mar. Geol. 272 (1-4), 6-25.

Guinasso, N.L., Schink, D.R., 1973. A simple physiochemical acoustic model of methane bubbles rising in the sea. In: Report Reference, 73-15-T. Texas A\&M University, College of Geosciences.

Gullapalli, S., Dewangan, P., Kumar, A., Dakara, G., Mishra, C.K., 2019. Seismic evidence of free gas migration through the gas hydrate stability zone (GHSZ) and active methane seep in Krishna-Godavari offshore basin. Mar. Petrol. Geol. 110, 695-705.

Gupta, S.K., 2006. Basin architecture and petroleum system of Krishna Godavari Basin, east coast of India. Lead. Edge 25, 830.

Haacke, R.R., Hyndman, R.D., Park, K.-P., Yoo, D.-G., Stoian, I., Schmidt, U., 2009. Migration and venting of deep gases into the ocean through hydrate-choked chimneys offshore Korea. Geology 37 (6), 531-534.

Heeschen, K.U., Tréhu, A.M., Collier, R.W., Suess, E., Rehder, G., 2003. Distribution and height of methane bubble plumes on the Cascadia Margin characterized by acoustic imaging. Geophys. Res. Lett. 30 (12), 1-4.

Henry, P., Lallemant, S., Nakamura, K., Tsunogai, U., Mazzotti, S., Kobayashi, K., 2002. Surface expression of fluid venting at the toe of the Nankai wedge and implications for flow paths. Mar. Geol. 187 (1-2), 119-143.

Hornafius, J.S., Quigley, D., Luyendyk, B.P., 1999. The world's most spectacular marine hydrocarbon seeps (Coal Oil Point, Santa Barbara Channel, California): quantification of emissions. J. Geophys. Res. 104 (C9), 20703-20711.

Hovland, M., 1990. Suspected gas-associated clay diapirism on the seabed off Mid Norway. Mar. Petrol. Geol. 7 (3), 267-276.
Hovland, M., 2007. Discovery of profilic natural methane seeps at Gullfaks northern North Sea. Geo Mar. Lett. 27, 197-201.

Hovland, M., Curzi, P.V., 1989. Gas seepage and assumed mud diapirism in the Italian central Adriatic Sea. Mar. Petrol. Geol. 6 (2), 161-169.

Hovland, M., Judd, A.G., 1988. Seabed Pockmarks and Seepages: Impact on Geology, biology and the Marine Environment. Graham and Trotman Ltd., London, p. 293.

Hovland, M., Jensen, S., Fichler, C., 2012. Methane and minor oil macro-seep systems their complexity and environmental significance. Mar. Geol. 332- 334, 163-173.

Johnson, H.P., Miller, U.K., Salmi, M.S., Solomon, E.A., 2015. Analysis of bubble plume distributions to evaluate methane hydrate decomposition on the continental slope. G-cubed 16 (11), 3825-3839.

Joshi, R.K., Mazumdar, A., Peketi, A., Ramamurty, P.B., Naik, B.G., Kocherla, M., Carvalho, M.A., Mahalakshmi, P., Dewangan, P., Ramana, M.V., 2014. Gas hydrate destabilization and methane release events in the Krishna-Godavari Basin, Bay of Bengal. Mar. Petrol. Geol. 58, 476-489.

Judd, A.G., 2003. The global importance and context of methane escape from the seabed. Geo Mar. Lett. 23, 147-154.

Judd, A.G., Hovland, M., 2007. Seabed Fluid Flow: the Impact on Geology, Biology, and the Marine Environment. Cambridge University Press, p. 475.

Judd, A.G., Hovland, M., Dimitrov, L.I., García Gil, S., Jukes, V., 2002. The geological methane budget at Continental Margins and its influence on climate change. Geofluids 2, 109-126.

Ketzer, J.M., Augustin, A., Rodrigues, L.F., Oliveira, R., Praeg, D., Pivel, M.A.G., dos Reis, A.T., Silva, C., Leonel, B., 2018. Gas seeps and gas hydrates in the Amazon deep-sea fan. Geo Mar. Lett. 38, 429-438.

Knittel, K., Boetius, A., 2009. Anaerobic oxidation of methane: progress with an unknown process. Annu. Rev. Microbiol. 63, 311-334.

Krabbenhoeft, A., Bialas, J., Klaucke, I., Crutchley, G., Papenberg, C., Netzeband, G.L., 2013. Patterns of subsurface fluid-flow at cold seeps: the Hikurangi Margin, offshore New Zealand. Mar. Petrol. Geol. 39, 59-73.

Kumar, P., Collett, T.S., Boswell, R., Cochran, J.R., Lall, M., Mazumdar, A., Ramana, M. V., Ramprasad, T., Riedel, M., Sain, K., Sathe, A.V., Vishwanath, K., Yadav, U.S., 2014. Geologic implications of gas hydrates in the offshore of India: krishna-godavari basin, Mahanadi basin, andaman sea, Kerala-konkan basin. Mar. Petrol. Geol. 58, 29-98.

Kumar, P., Collett, T.S., Shukla, K.M., Yadav, U.S., Lall, M.V., Vishwanath, K., 2019. India national gas hydrate program expedition-02: operational and technical summary. Mar. Petrol. Geol. 108, 3-38.

Kvenvolden, K.A., Rogers, B.W., 2005. Gaia's breath—global methane exhalations. Mar. Petrol. Geol. 22, 579-590.

Lambeck, K., Rouby, H.L.N., Purcell, A., Sun, Y., Sambridge, M., 2014. sea level and global ice volumes from the last glacial maximum to the holocene. Proc. Natl. Acad. Sci. Unit. States Am. 111, 15296-15303.

Law, C.S., Nodder, S.D., Mountjoy, J.J., Marriner, A., Orpin, A., Pilditch, C.A., Franz, P., Thompson, K., 2010. Geological, hydrodynamic and biogeochemical variability of a New Zealand deep-water methane cold seep during an integrated three-year timeseries study. Mar. Geol. 272 (1-4), 189-208.

Le Pichon, X., Iiyama, T., Boulègue, J., Charvet, J., Faure, M., Kano, K., Lallemant, S., Okada, H., Rangin, C., Taira, A., Urabe, T., Uyeda, S., 1987. Nankai trough and zenisu ridge: a Deep-sea submersible survey. Earth Planet Sci. Lett. 83 (1-4), 285-299.

Leifer, I., MacDonald, I., 2003. Dynamics of the gas flux from shallow gas hydrate deposits: interaction between oily hydrate bubbles and the oceanic environment. Earth Planet Sci. Lett. 210 (3-4), 411-424.

Liu, X., Flemings, P.B., 2007. Dynamic multiphase flow model of hydrate formation in marine sediments. J. Geophys. Res. 112 (B3), 1-23.

Loher, M., Pape, T., Marcon, Y., Römer, M., Wintersteller, P., Praeg, D., Torres, M., Sahling, H., Bohrmann, G., 2018. Mud extrusion and ring-fault gas seepage - upward branching fluid discharge at a deep-sea mud volcano. Sci. Rep. 8 (1), 1-11.

Loncke, L., Mascle, J., 2004. Mud volcanoes, gas chimneys, pockmarks and mounds in the Nile deep-sea fan (Eastern Mediterranean): geophysical evidences. Mar. Petrol. Geol. 21 (6), 669-689.

Løseth, H., Wensaas, L., Arntsen, B., Hanken, N.-M., Basire, C., Graue, K., 2011. 1000 m long gas blow-out pipes. Mar. Petrol. Geol. 28 (5), 1047-1060.

Lüdmann, T., Wong, H.K.K., 2003. Characteristics of gas hydrate occurrences associated with mud diapirism and gas escape structures in the northwestern Sea of Okhotsk. Mar. Geol. 201 (4), 269-286.

Malinverno, A., Goldberg, D.S., 2015. Testing short-range migration of microbial methane as a hydrate formation mechanism : results from Andaman Sea and Kumano Basin drill sites and global implications. Earth Planet Sci. Lett. 422, 105-114.

Mandal, R., Dewangan, P., Ramprasad, T., Kumar, B.J.P., Vishwanath, K., 2014. Effect of thermal non-equilibrium, seafloor topography and fluid advection on BSR-derived geothermal gradient. Mar. Petrol. Geol. 58, 368-381.

Mazumdar, A., Dewangan, P., Joäo, H.M., Peketi, A., Khosla, V.R., Kocherla, M., Badesab, F.K., Joshi, R.K., Roxanne, P., Ramamurty, P.B., Karisiddaiah, S.M., Patil, D.J., Dayal, A.M., Ramprasad, T., Hawkesworth, C.J., Avanzinelli, R., 2009. Evidence of paleo-cold seep activity from the Bay of Bengal, offshore India. G-cubed 10 (6), 1-15.

Mazumdar, A., Dewangan, P., Peketi, A., Gullapalli, S., Kalpana, M.S., Naik, G.P. Shetty, D., Pujari, S., Pillutla, S.P.K., Gaikwad, V.V., Nazareth, D., Sangodkar, N.S., Dakara, G., Kumar, A., Mishra, C.K., Singha, P., Reddy, R., 2019. The first record of active methane (cold) seep ecosystem associated with shallow methane hydrate from the Indian EEZ. J. Earth Syst. Sci. 128, 18.

McGinnis, D.F., Greinert, J., Artemov, Y., Beaubien, S.E., Wüest, A., 2006. Fate of rising methane bubbles in stratified waters: how much methane reaches the atmosphere? J. Geophys. Res. Ocean. 111, C09007. 
Merewether, R., Olsson, M.S., Lonsdale, P., 1985. Acoustically detected hydrocarbon plumes rising from 2-km depths in Guaymas Basin, Gulf of California. J. Geophys. Res. Solid Earth 90 (B4), 3075-3085.

Meyer, D.W., Flemings, P.B., DiCarlo, D., You, K., Phillips, S.C., Kneafsey, T.J., 2018 Experimental investigation of gas flow and hydrate formation within the hydrate stability zone. J. Geophys. Res. 123, 5350-5371. https://doi.org/10.1029/ 2018JB015748.

Meyer, D.W., Flemings, P.B., You, K., Dicarlo, D.A., 2020. Gas flow by invasion percolation through the hydrate stability zone. Geophys. Res. Lett. 1-9. https://doi. org/10.1029/2019GL084380.

Miles, P.R., 1995. Potential distribution of methane hydrate beneath the European continental margins. Geophys. Res. Lett. 22, 3179-3182.

Milkov, A.V., Sassen, R., Apanasovich, T.V., Dadashev, F.G., 2003. Global gas flux from mud volcanoes: a significant source of fossil methane in the atmosphere and the ocean. Geophys. Res. Lett. 30 (2), 1037. https://doi.org/10.1029/2002GL016358.

Mishra, C.K., Dewangan, P., Sriram, G., Kumar, A., Dakara, G., 2019. Spatial distribution of gas hydrate deposits in Krishna-Godavari o ff shore basin, Bay of Bengal. Mar. Petrol. Geol. 112, 104037. https://doi.org/10.1016/j.marpetgeo.2019.104037.

Moore, J.C., Orange, D., Kulm, L.D., 1990. Interrelationship of fluid venting and structural evolution: alvin observations from the frontal accretionary prism, Oregon. J. Geophys. Res. Solid Earth 95 (B6), 8795-8808.

Murthy, K.S.R., Rao, T.C.S., 1990. Acoustic wipeouts over the conti- nental margins off Krishna, Godavari and Mahanadi river basins, east coast of India. J. Geol. Soc. India $35,558-569$.

Naudts, L., Greinert, J., Artemov, Y., Staelens, P., Poort, J., Van Rensbergen, P., De Batist, M., 2006. Geological and morphological setting of 2778 methane seeps in the Dnepr paleo-delta, northwestern Black Sea. Mar. Geol. 227 (3-4), 177-199.

Naudts, L., Khlystov, O., Granin, N., Chensky, A., Poort, J., De Batist, M., 2012. Stratigraphic and structural control on the distribution of gas hydrates and active gas seeps on the Posolsky Bank, Lake Baikal. Geo Mar. Lett. 32 (5-6), 395-406.

Obzhirov, A., Shakirov, R., Salyuk, A., Suess, E., Biebow, N., Salomatin, A., 2004. Relations between methane venting, geological structure and seismo-tectonics in the Okhotsk Sea. Geo Mar. Lett. 24, 135-139. https://doi.org/10.1007/s00367-0040175-0.

Olu-Le Roy, K., Caprais, J.-C., Fifis, A., Fabri, M.-C., Galéron, J., Budzinsky, H., Le Ménach, K., Khripounoff, A., Ondréas, H., Sibuet, M., 2007. Cold-seep assemblages on a giant pockmark off West Africa: spatial patterns and environmental control. Mar. Ecol. 28 (1), 115-130.

Pape, T., Feseker, T., Kasten, S., Fischer, D., Bohrmann, G., 2011. Distribution and abundance of gas hydrates in near-surface deposits of the håkon mosby mud volcano, SW Barents sea. G-cubed 12 (9), 1-22.

Paull, C.K., Ussler III, W., Borowski, W.S., Spiess, F.N., 1995. Methane-rich plumes on the Carolina continental rise: associations with gas hydrates. Geology 23 (1), 89-92.

Paull, C.K., Brewer, P.G., Ussler, W., Peltzer, E.T., Rehder, G., Clague, D., 2002. An experiment demonstrating that marine slumping is a mechanism to transfer methane from seafloor gas-hydrate deposits into the upper ocean and atmosphere. Geo Mar. Lett. 22 (4), 198-203.

Paull, C.K., Normark, W.R., Ussler, W., Caress, D.W., Keaten, R., 2008. Association among active seafloor deformation, mound formation, and gas hydrate growth and accumulation within the seafloor of the Santa Monica Basin, offshore California. Mar. Geol. 250 (3-4), 258-275.

Pecher, I.A., Henrys, S.A., Wood, W.T., Kukowski, N., Crutchley, G.J., Fohrmann, M., Kilner, J., Senger, K., Gorman, A.R., Coffin, R.B., Greinert, J., Faure, K., 2010. Focussed fluid flow on the Hikurangi Margin, New Zealand - evidence from possible local upwarping of the base of gas hydrate stability. Mar. Geol. 272 (1-4), 99-113.

Peketi, A., Mazumdar, A., Joshi, R.K., Patil, D.J., Srinivas, P.L., Dayal, A.M., 2012. Tracing the Paleo sulfate-methane transition zones and H2S seepage events in marine sediments: an application of C-S-Mo systematics. G-cubed 13 (10), 1-11.

Plaza-Faverola, A., Bünz, S., Johnson, J.E., Chand, S., Knies, J., Mienert, J., Franek, P., 2015. Role of tectonic stress in seepage evolution along the gas hydrate-charged Vestnesa Ridge, Fram Strait. Geophys. Res. Lett. 42 (3), 733-742. https://doi.org/ 10.1002/2014GL062474.

Powell, C.M., Roots, S.R., Veevers, J.J., 1988. Pre-breakup continental extension in east Gondwanaland and the early opening of the eastern Indian Ocean. Tectonophysics 155, 261-283.

Prabhakar, K.N., Zutshi, P.L., 1993. Evolution of southern part of Indian East Coast basin. J. Geol. Soc. India 41, 215-230.

Ramana, M.V., Nair, R.R., Sarma, K.V.L.N.S., Ramprasad, T., Krishna, K.S., D’Cruz, M., Subrahmanyam, C., Paul, J., Subrahmanyam, A.S., Sekhar, D.V.C., 1994. Mesozoic anomalies in the Bay of bengal. V., S. Earth Planet Sci. Lett. 121 (3-4), 469-475.

Ramana, M.V., Ramprasad, T., Desa, M., Sathe, A.V., Sethi, A.K., 2006. Gas hydraterelated proxies inferred from multidisciplinary investigations in the India offshoe areas. Curr. Sci. 91, 183-189.

Ramana, M.V., Ramprasad, T., Paropkari, a.L., Borole, D.V., Rao, B.R., Karisiddaiah, S. M., Desa, M., Kocherla, M., Joao, H.M., Lokabharati, P., Gonsalves, M.J., Pattan, J. N., Khadge, N.H., Babu, C.P., Sathe, A.V., Kumar, P., Sethi, A.K., 2009. Multidisciplinary investigations exploring indicators of gas hydrate occurrence in the Krishna-Godavari Basin offshore, east coast of India. Geo Mar. Lett. 29 (1), 25-38.

Ramprasad, T., Dewangan, P., Ramana, M.V., Mazumdar, A., Karisiddaiah, S.M., Ramya, E.R., Sriram, G., 2011. Evidence of slumping/sliding in Krishna-Godavari offshore basin due to gas/fluid movements. Mar. Petrol. Geol. 28 (10), 1806-1816.
Rao, G.N., 1993. Geology and hydrocarbon prospects of East Coast sedimentary basin of India with special reference to Krishna-Godavari Basin. J. Geol. Soc. India 41 (5), 444-454.

Rao, G.N., 2001. Sedimentation, stratigraphy, and petroleum potential of KrishnaGodavari basin, East Coast of India. Am. Assoc. Petrol. Geol. Bull. 85 (9), 1623-1643.

Rao, G.N., Mani, K.S., 1993. A study on generation of abnormal pressures in Krishna Godavari basin. Indian J. Petrol Geol. 2, 20-30.

Rastogi, A., Deka, B., Bhattacharya, G., Ramprasad, T., Kamesh Raju, K.A., Srinivas, K., Murthy, G.P.S., Chaubey, A.K., Ramana, M.V., Subrahmanyam, V., Sarma, K.V.L.N. S., Desa, M., Paropkari, A.L., Menezes, A.A.A., Murthy, V.S.N., Anthony, M.K., Subba Raju, L.V., Desa, E., Veerayya, M., 1999. Gas hydrate stability zone thickness map of Indian offshore areas - a GIS based approach. Petrotech-99 Proceedings of Third International Petroleum Conference \& Exbn, pp. 489-494.

Reeburgh, W.S., 2007. Oceanic methane biogeochemistry. Chem. Rev. 107 (2), 486-513.

Rehder, G., Brewer, P.W., Peltzer, E.T., Friederich, G., 2002. Enhanced lifetime of methane bubble streams within the deep ocean. Geophys. Res. Lett. 29 (15), 21-24.

Riedel, M., Collett, T.S., Kumar, P., Sathe, a.V., Cook, a., 2010. Seismic imaging of a fractured gas hydrate system in the Krishna-Godavari Basin offshore India. Mar. Petrol. Geol. 27 (7), 1476-1493.

Römer, M., Sahling, H., Pape, T., Bahr, A., Feseker, T., Wintersteller, P., Bohrmann, G., 2012. Geological control and magnitude of methane ebullition from a high-flux seep area in the Black Sea-the Kerch seep area. Mar. Geol. 319-322, 57-74.

Römer, M., Sahling, H., Pape, T., dos Santos Ferreira, C., Wenzhöfer, F., Boetius, A., Bohrmann, G., 2014. Methane fluxes and carbonate deposits at a cold seep area of the central nile deep sea fan, eastern mediterranean sea. Mar. Geol. 347, 27-42.

Römer, M., Hsu, C.-W., Loher, M., MacDonald, I.R., dos Santos Ferreira, C., Pape, T., Mau, S., Bohrmann, G., Sahling, H., 2019. Amount and fate of gas and oil discharged at $3400 \mathrm{~m}$ water depth from a natural seep site in the Southern Gulf of Mexico. Front. Mar. Sci. 6, 700. https://doi.org/10.3389/fmars.2019.00700.

Rudolph, M.L., Manga, M., 2010. mud volcano response to the 4 april 2010 el mayorcucapah earthquake. J. Geophys. Res. 115, B12211. https://doi.org/10.1029/ $2010 J B 007737$.

Ruppel, C., Dickens, G.R., Castellini, D.G., Gilhooly, W., Lizarralde, D., 2005. Heat and salt inhibition of gas hydrate formation in the northern Gulf of Mexico. Geophys. Res. Lett. 32 (4), 1-4.

Schneider von Deimling, J., Rehder, G., Greinert, J., McGinnnis, D.F., Boetius, A., Linke, P., 2011. Quantification of seep-related methane gas emissions at Tommeliten, North Sea. Continent. Shelf Res. 31 (7-8), 867-878.

Scotese, C.R., Gahagan, L.M., Larson, R.L., 1988. Plate tectonic reconstructions of the Cretaceous and Cenozoic ocean basins. Tectonophysics 155 (1-4), 27-48.

Singha, D.K., Chatterjee, R., 2014. Detection of overpressure zones and a statistical model for pore pressure estimation from well logs in the Krishna-Godavari Basin, India. G-cubed 15, 1009-1020.

Skarke, A., Ruppel, C., Kodis, M., Brothers, D., Lobecker, E., 2014. Widespread methane leakage from the sea floor on the northern US Atlantic margin. Nat. Geosci. 7 (9), $657-661$.

Sloan, E.D., Koh, C., 2007. Clathrate Hydrates of Natural Gases. CRC Press.

Sriram, G., Dewangan, P., Ramprasad, T., Rama Rao, P., 2013. Anisotropic amplitude variation of the bottom-simulating reflector beneath fracture-filled gas hydrate deposit. J. Geophys. Res. Solid Earth 118 (5), 2258-2274.

Tsunogai, U., Maegawa, K., Sato, S., Komatsu, D.D., Nakagawa, F., Toki, T., Ashi, J., 2012. Coseimic massive methane release from a submarine mud volcano. Earth Planet Sci. Lett. 341-344, 79-85.

Vagle, S., Farmer, D.M., 1992. The measurement of bubble-size distributions by acoustical backscatter. J. Atmos. Ocean. Technol. 9 (5), 630-644.

Vanneste, M., De Batist, M., Golmshtok, a, Kremlev, a, Versteeg, W., 2001. Multifrequency seismic study of gas hydrate-bearing sediments in Lake Baikal, Siberia. Mar. Geol. 172 (1-2), 1-21.

Veloso, M., Greinert, J., Mienert, J., De Batist, M., 2015. A new methodology for quantifying bubble flow rates in deep water using splitbeam echosounders: examples from the Arctic offshore NW-Svalbard. Limnol Oceanogr. Methods 13 (6), 267-287.

Vijayalakshmi, K.G., 1988. Miocene depositional systems in thrust areas in KrishnaGodavari basin. Bull. Oil Nat. Gas Comm. 25 (2), 1-10.

Wenau, S., Spiess, V., Pape, T., Fekete, N., 2015. Cold seeps at the salt front in the Lower Congo Basin I: current methane accumulation and active seepage. Mar. Petrol. Geol. 67, 894-908.

Wenau, S., Spiess, V., Keil, H., Fei, T., 2018. Localization and characterization of a gas bubble stream at a Congo deep water seep site using a 3D gridding approach on single-beam echosounder data. Mar. Petrol. Geol. 97, 612-623.

Westbrook, G.K., Thatcher, K.E., Rohling, E.J., Piotrowski, A.M., Pälike, H., Osborne, A. H., Nisbet, E.G., Minshull, T.a., Lanoisellé, M., James, R.H., Hühnerbach, V., Green, D., Fisher, R.E., Crocker, A.J., Chabert, A., Bolton, C., Beszczynska-Möller, A., Berndt, C., Aquilina, A., 2009. Escape of methane gas from the seabed along the West Spitsbergen continental margin. Geophys. Res. Lett. 36 (15), 1-5.

Wood, W.T., Gettrust, J.F., Chapman, N.R., Spence, G.D., Hyndman, R.D., 2002 Decreased stability of methane hydrates in marine sediments owing to phaseboundary roughness. Nature 420 (6916), 656-660.

You, K., Flemings, P.B., 2018. Methane hydrate formation in thick sandstones by free gas flow. J. Geophys. Res. 123 (6), 4582-4600.

You, K., Flemings, P.B., Malinverno, A., Collett, T.S., Darnell, K., 2019. Mechanisms of methane hydrate formation in geological systems. Rev. Geophys. 57 (4), 1146-1196. 